\title{
Effect of Different Nitrogen Doses on Various Characters against Foliar Blight of Wheat (Triticum aestivum L.)
}

\author{
Ghanshyam verma*, S.P. Singh, S.K. Singh, Chandra Pal, \\ Sheetala Varma and Nutan Singh
}

Department of of Plant Pathology, N. D. University, Kumarganj, Faizabad (U.P.), India

*Corresponding author

A B S T R A C T

Keywords

Wheat, (Triticum aestivum), Host nutrition, Foliar blight, Bipolaris sorokiniana, Plant height, Ear length

Article Info

Accepted:

15 October 2018

Available Online:

10 November 2018
A field experiment was conducted to study the effects of different doses $(60,80,100,120$, and $140 \mathrm{~kg} / \mathrm{ha})$ of nitrogen application on $100 \mathrm{~kg} / \mathrm{ha}$ seed rate a semi dwarf, high yielding with good quality traits on 'DBW 17', variety of wheat was evaluated to study the effect of $100 \mathrm{~kg} /$ ha seed rate and different doses of nitrogen application on percent disease intensity, AUDPC, and yield of wheat. The results showed that different doses $120 \mathrm{~kg} / \mathrm{ha}$ nitrogen and $100 \mathrm{~kg} / \mathrm{ha}$ seed rate significantly out yielded the 100 $\mathrm{kg} / \mathrm{ha}$ and $140 \mathrm{~kg} / \mathrm{ha}$ nitrogen and seed rate in seed yield. Almost similar result were obtained in case of plant height $(\mathrm{cm})$, spike length $(\mathrm{cm}$.), number of tillers/plant, 1000 seed weight $(\mathrm{gm})$.

\section{Introduction}

Wheat (Triticum aestivum L.) belongs to the family Poaceae. It is the most important cereal crop after rice in India and is the most important food of about two billion people (36\% of the world population). The common bread wheat, $T$. aestivum, is the most important species, occupying more than $90 \%$ of the wheat area and $87 \%$ of the total wheat production in the country. In world, Wheat is grown over 224.7 million hectare area with production of 734.80 million metric tons and yield of 3.27 metric tons per hectare. In India, wheat is grown over 31.47 million hectare area with production of 86.53 million metric tons and yield of 2.75 metric tons per hectare (Anonymous, 2016) about $91 \%$ of the total wheat production is contributed by northern states. Among them, Uttar Pradesh rank first with respect to area (9.645 m.ha.) and production of $(30.00$ m.t.) but the average productivity (27.86 q/ha) is much lower as compare to Punjab and Haryana (Anonymous, 
2016). Wheat is nature's unique gift to mankind as it is an excellent source of nutrition. Wheat is nature's unique gift to mankind as it produces excellent source of nutrition in terms of carbohydrates, minerals and proteins. Although wheat is grown in most of the states, the major production comes from the north western part of the country. The increase in domestic demand of baked and pasta products in the country and economic liberalization and global trade have offered opportunities for better utilization of wheat. Wheat quality needs uppermost attention to meet the trade requirements of the domestic and international markets. Quality of food grain is a complex phenomenon and may be influenced by several factors which may be genetic and /or environmental. Cultural practices considerably influence the grain quality. Adoption of suitable practices different nitrogen application play a key role on the quality of wheat. Nitrogen is the most important constituent of plant proteins and is required throughout the crop growth period from vegetative stage to subsequent harvesting. Application of nitrogen is known to mainly increase the grain yield, and other characters including plant height and 1000 seed weight etc. Many researchers have found that late season top dressed nitrogen addition as dry fertilizer material were most effective in attaining higher grain protein concentration, yield and increased fertilizer recovery and efficiency (Satyanarayana., 2015) and (Parveen Kousar et al., 2015). Therefore, availability of nitrogen to wheat during various phases of its growth and development is an important factor influencing the yield and quality of grain (Muhammad Yousaf et al., 2015). Nitrogen level and 100kg/ha seed rate also plays a key role in the grain yield and quality of wheat. Seed rate governs the inter and intra plant competition, the numbers of tillers per plant, spikelet number per spike, grain size, grain shape etc. Likewise nitrogen nutrition, also influences the plant growth, development, seed size and other qualities of wheat. Although sufficient information is available on the effect of fertilizers on yield attributes but the information on the effect of time of nitrogen application and seed rate on biochemical parameters is meager Keeping this aspect in mind, the present investigation is planned with the objectives to study the impact of different doses of nitrogen application $(60,80,100.120$ and $140 \mathrm{~kg} / \mathrm{ha})$ on seed yield, and other characters and its quality in a national variety ' $\mathrm{DBW}-17$ ' of wheat (Triticum aestivum L.) in the agro-climatic condition of Faizabad region (U.P.).

\section{Materials and Methods}

The present investigation was carried out on Wheat cultivar 'DBW 17' at the student instructional farm Narendradev university of agriculture \& technology kumarganj faizabad (U.P.) during rabi (winter) season of 2014-15 and 2015-16. The treatment comprising of five levels of nitrogen viz- 60, 80, 100, 120 and $140 \mathrm{~kg} / \mathrm{ha}$ and $100 \mathrm{~kg} / \mathrm{ha}$ seed rate were laidout in randomized block design with three replications each. Thus total number of treatment combination were 05 with over check(untreated), plot size was $1.38 \times 7=9.66 \mathrm{~m} 2$, row to row spacing was 23 $\mathrm{cm}$, Urea was the sources of nitrogen. The observation were recorded on percent disease intensity(PDI), AUDPC, ear length(cm), plant height $(\mathrm{cm})$, number of tillers /plant, 1000 grain weight.

Percent disease intensity was calculated by employing the formula:

Mc Kinney (1975)

P.D.I. $=\frac{\text { Sum of total numerical rating }}{\text { Total number of leaves examined } x \text { Highest rating }} \times 100$

AUDPC: Disease severity calculated as per (Dubin et al., 1998). The formula was used as follows: 
$\sum_{i}^{n-1}\left[\left(\frac{y_{i}+y_{i+1}}{2}\right)\left(t_{i+1}-t_{i}\right)\right]$

\section{Results and Discussion}

For the use of proper quality of fertilizers in most essential for enhancing yield and quality important inputs for increasing productivity of this crop, therefore these fertilizer were tried to find their role in wheat crop and the results of present study are discussed.

All the treatments were significantly superior over check (untreated plot) in reducing the disease severity. Minimum percent disease intensity in first year (29.55\%) AUDPC (314.0) and second year (28.54\%) AUDPC (300.4) were recorded with the treatment $\mathrm{T}_{4}$ (Nitrogen doses of $120 \mathrm{~kg} / \mathrm{ha}$ ) followed by treatment $\mathrm{T}_{3}$ (Nitrogen doses of $100 \mathrm{~kg} / \mathrm{ha}$ ) and $\mathrm{T}_{5}$ (Nitrogen doses of $140 \mathrm{~kg} / \mathrm{ha}$ ) which have disease intensity of first year $32.62 \%$ or AUDPC (359.5) and $33.92 \%$ or AUDPC (403.9) and second year (32.89) or AUDPC (346.0) and (33.83) or AUDPC (398.0), respectively. Former treatment was significantly superior over the latter (Table 1 and 2).

Table.1 Effect of different nitrogen doses on severity of foliar blight- (2014-15)

\begin{tabular}{|c|c|c|c|c|c|c|}
\hline \multirow{2}{*}{ Treatment } & \multirow{2}{*}{$\begin{array}{c}\text { N. Doses } \\
\mathrm{Kg} / \mathrm{ha}\end{array}$} & \multirow{2}{*}{$\begin{array}{c}\text { Date of } \\
\text { disease } \\
\text { appearance }\end{array}$} & \multicolumn{3}{|c|}{ Percent disease intensity } & \multirow[t]{2}{*}{ AUDPC } \\
\hline & & & $12 / 3 / 2014$ & $19 / 3 / 2014$ & $26 / 3 / 2014$ & \\
\hline $\mathrm{T}_{1}$ & 60 & $26 / 1 / 15$ & $\begin{array}{c}20.96 \\
(27.20)\end{array}$ & $\begin{array}{c}29.26 \\
(32.71)\end{array}$ & $\begin{array}{c}36.27 \\
(36.99)\end{array}$ & 405.1 \\
\hline $\mathrm{T}_{2}$ & 80 & $24 / 1 / 15$ & $\begin{array}{c}22.19 \\
(28.04)\end{array}$ & $\begin{array}{c}28.74 \\
(32.39)\end{array}$ & $\begin{array}{c}35.20 \\
(36.39)\end{array}$ & 402.0 \\
\hline $\mathrm{T}_{3}$ & 100 & $26 / 1 / 15$ & $\begin{array}{c}15.48 \\
(23.11)\end{array}$ & $\begin{array}{c}26.81 \\
(31.18)\end{array}$ & $\begin{array}{c}33.62 \\
(35.43)\end{array}$ & 359.5 \\
\hline $\mathrm{T}_{4}$ & 120 & $26 / 1 / 15$ & $\begin{array}{c}11.39 \\
(19.64)\end{array}$ & $\begin{array}{c}24.39 \\
(29.53)\end{array}$ & $\begin{array}{c}29.55 \\
(32.54)\end{array}$ & 314.0 \\
\hline $\mathrm{T}_{5}$ & 140 & $25 / 1 / 15$ & $\begin{array}{c}21.67 \\
(27.69)\end{array}$ & $\begin{array}{c}30.40 \\
(33.46)\end{array}$ & $\begin{array}{c}32.92 \\
(35.00)\end{array}$ & 403.9 \\
\hline $\mathrm{T}_{6}$ & 00 & $21 / 1 / 15$ & $\begin{array}{c}27.67 \\
(31.63)\end{array}$ & $\begin{array}{c}32.86 \\
(34.94)\end{array}$ & $\begin{array}{c}37.61 \\
(37.82)\end{array}$ & 458.5 \\
\hline SEm \pm & & & 0.886 & 1.793 & 0.718 & \\
\hline $\mathrm{CD}$ & & & 2.669 & 5.404 & 3.165 & \\
\hline
\end{tabular}


Int.J.Curr.Microbiol.App.Sci (2018) 7(11): 1918-1924

Table.2 Effect of different nitrogen doses on severity of foliar blight- (2015-16

\begin{tabular}{|c|c|c|c|c|c|c|}
\hline \multirow[t]{2}{*}{ Treatment } & \multirow{2}{*}{$\begin{array}{c}\text { N. Doses } \\
\text { Kg/ha }\end{array}$} & \multirow{2}{*}{$\begin{array}{c}\text { Date of disease } \\
\text { appearance }\end{array}$} & \multicolumn{3}{|c|}{ Percent disease intensity } & \multirow[t]{2}{*}{ AUDPC } \\
\hline & & & $13 / 3 / 2015$ & $20 / 3 / 2015$ & $27 / 3 / 2015$ & \\
\hline $\mathrm{T}_{1}$ & 60 & $26 / 2 / 15$ & $\begin{array}{c}19.28 \\
(25.99)\end{array}$ & $\begin{array}{c}28.74 \\
(32.39)\end{array}$ & $\begin{array}{c}35.58 \\
(36.57)\end{array}$ & 393.2 \\
\hline $\mathrm{T}_{2}$ & 80 & $24 / 2 / 15$ & $\begin{array}{c}21.91 \\
(27.90)\end{array}$ & $\begin{array}{c}27.74 \\
(31.76)\end{array}$ & $\begin{array}{c}34.06 \\
(35.67)\end{array}$ & 390.0 \\
\hline $\mathrm{T}_{3}$ & 100 & $26 / 2 / 15$ & $\begin{array}{c}14.38 \\
(22.22)\end{array}$ & $\begin{array}{c}25.80 \\
(30.53)\end{array}$ & $\begin{array}{c}32.89 \\
(34.94)\end{array}$ & 346.0 \\
\hline $\mathrm{T}_{4}$ & 120 & $26 / 2 / 15$ & $\begin{array}{c}10.73 \\
(19.09)\end{array}$ & $\begin{array}{c}23.28 \\
(28.79)\end{array}$ & $\begin{array}{c}28.54 \\
(32.27)\end{array}$ & 300.4 \\
\hline $\mathrm{T}_{5}$ & 140 & $25 / 2 / 15$ & $\begin{array}{c}20.01 \\
(26.56)\end{array}$ & $\begin{array}{c}29.95 \\
(33.15)\end{array}$ & $\begin{array}{c}33.83 \\
(35.55)\end{array}$ & 398.0 \\
\hline $\mathrm{T}_{6}$ & 00 & $22 / 2 / 15$ & $\begin{array}{c}26.50 \\
(30.33)\end{array}$ & $\begin{array}{c}31.08 \\
(33.83)\end{array}$ & $\begin{array}{c}36.97 \\
(37.41)\end{array}$ & 439.7 \\
\hline SEm \pm & & & 1.48 & 1.37 & 2.72 & \\
\hline $\mathrm{CD}$ & & & 4.45 & 4.13 & 8.20 & \\
\hline
\end{tabular}

Table.3 Effect of different nitrogen doses on Plant height, Ear length, No. of tillers 2014-15

\begin{tabular}{|c|c|c|c|c|c|c|c|c|c|c|}
\hline Treatment & N. Doses & \multicolumn{3}{|c|}{ Plant height } & \multicolumn{3}{|c|}{ Ear length } & \multicolumn{3}{c|}{ No. of tillers } \\
\hline T1 & 60 KG & 75.36 & 83.96 & 84.07 & 7.9 & 8.1 & 8.3 & 5.2 & 5.5 & 6.6 \\
\hline T2 & 80 KG & 78.97 & 84.77 & 89.86 & 8.3 & 8.4 & 8.5 & 5.1 & 5.9 & 6.9 \\
\hline T3 & 100 KG & 83.36 & 86.61 & 91.58 & 8.5 & 8.6 & 8.7 & 5.3 & 6.3 & 7.7 \\
\hline T4 & 120 KG & 81.52 & 88.10 & 94.72 & 8.7 & 8.9 & 9.2 & 6.2 & 7.5 & 8.9 \\
\hline T5 & 140 KG & 77.74 & 83.62 & 93.26 & 8.5 & 8.7 & 8.9 & 6.4 & 7.2 & 8.2 \\
\hline T6 & 00 KG & 72.49 & 76.41 & 80.53 & 7.6 & 7.7 & 7.9 & 3.8 & 4.2 & 5.3 \\
\hline SEm \pm & & $\mathbf{3 . 0 4 8}$ & $\mathbf{0 . 9 5 1}$ & $\mathbf{0 . 8 0 9}$ & $\mathbf{0 . 1 1 5}$ & $\mathbf{0 . 0 7 9}$ & $\mathbf{0 . 0 7 9}$ & $\mathbf{0 . 3 4 1}$ & $\mathbf{0 . 3 8 3}$ & $\mathbf{0 . 1 8 2}$ \\
\hline CD & & $\mathbf{9 . 1 8 7}$ & $\mathbf{2 . 8 6 5}$ & $\mathbf{2 . 4 3 8}$ & $\mathbf{0 . 3 4 8}$ & $\mathbf{0 . 2 3 9}$ & $\mathbf{0 . 2 3 9}$ & $\mathbf{1 . 0 2 7}$ & $\mathbf{1 . 1 5 4}$ & $\mathbf{0 . 5 4 9}$ \\
\hline
\end{tabular}


Table.4 Effect of different nitrogen doses on Plant height, Ear length, No. of tillers 2015-16

\begin{tabular}{|c|r|r|r|r|r|r|r|r|r|r|}
\hline Treatment & N.Doses & \multicolumn{3}{|c|}{ Plant height } & \multicolumn{3}{|c|}{ Ear length } & \multicolumn{3}{|c|}{ No. of tillers } \\
\hline T1 & 60 KG & 76.97 & 84.30 & 86.29 & 8.1 & 8.3 & 8.4 & 6.1 & 6.5 & 7.3 \\
\hline T2 & 80 KG & 82.31 & 86.27 & 91.01 & 8.5 & 8.6 & 8.6 & 5.6 & 7.2 & 7.4 \\
\hline T3 & $100 \mathrm{KG}$ & 84.40 & 88.29 & 92.06 & 8.7 & 8.7 & 8.9 & 6.2 & 7.1 & 7.9 \\
\hline T4 & $120 \mathrm{KG}$ & 81.55 & 89.36 & 94.49 & 8.9 & 9.1 & 9.4 & 6.6 & 7.9 & 9.1 \\
\hline T5 & $140 \mathrm{KG}$ & 79.16 & 85.69 & 94.82 & 8.8 & 8.9 & 9.1 & 6.6 & 7.8 & 8.3 \\
\hline T6 & 00 KG & 73.36 & 77.66 & 81.95 & 7.7 & 7.7 & 7.8 & 3.5 & 3.7 & 5.1 \\
\hline SEm \pm & & $\mathbf{2 . 7 4}$ & $\mathbf{1 . 5 2}$ & $\mathbf{1 . 3 6}$ & $\mathbf{0 . 1 3}$ & $\mathbf{0 . 1 0}$ & $\mathbf{0 . 1 4}$ & $\mathbf{0 . 3 7}$ & $\mathbf{0 . 4 7}$ & $\mathbf{0 . 2 6}$ \\
\hline CD & & $\mathbf{8 . 2 7}$ & $\mathbf{4 . 5 9}$ & $\mathbf{4 . 0 9}$ & $\mathbf{0 . 4 0}$ & $\mathbf{0 . 2 9}$ & $\mathbf{0 . 4 3}$ & $\mathbf{1 . 1 2}$ & $\mathbf{1 . 4 2}$ & $\mathbf{0 . 7 9}$ \\
\hline
\end{tabular}

Table.5 Effect of different nitrogen doses on yield $\mathrm{kg} / \mathrm{plot}$ or q/ha and 1000 grain weight-2014-15

\begin{tabular}{|c|c|c|c|c|}
\hline Treatment & $\begin{array}{c}\text { N. Doses } \\
\text { Kg/ha }\end{array}$ & Yield/ plot & Yield q/ha & 1000 grain wt. \\
\hline $\mathrm{T}_{1}$ & 60 & 4.190 & 43.37 & 41.06 \\
\hline $\mathrm{T}_{2}$ & 80 & 4.353 & 45.05 & 41.14 \\
\hline $\mathrm{T}_{3}$ & 100 & 4.415 & 47.25 & 41.60 \\
\hline $\mathrm{T}_{4}$ & 120 & 4.665 & 48.28 & 42.02 \\
\hline $\mathrm{T}_{5}$ & 140 & 4.413 & 46.21 & 41.39 \\
\hline $\mathrm{T}_{6}$ & 00 & 3.871 & 41.30 & 40.36 \\
\hline $\mathrm{SEm} \pm$ & & $\mathbf{0 . 1 7}$ & $\mathbf{1 . 5 2}$ & $\mathbf{0 . 4 2}$ \\
\hline $\mathrm{CD}$ & & $\mathbf{0 . 5 1}$ & $\mathbf{4 . 5 8}$ & $\mathbf{1 . 2 8}$ \\
\hline
\end{tabular}

Table.6 Effect of different nitrogen doses on yield $\mathrm{kg} / \mathrm{plot}$ or $\mathrm{q} / \mathrm{ha}$ and 1000 grain weight-2015-16

\begin{tabular}{|c|c|c|c|c|}
\hline Treatment & $\begin{array}{c}\text { N. Doses } \\
\text { Kg/ha }\end{array}$ & Yield/ plot & Yield q/ha & 1000 grain wt. \\
\hline $\mathrm{T}_{1}$ & 60 & 4.285 & 44.35 & 40.56 \\
\hline $\mathrm{T}_{2}$ & 80 & 4.478 & 46.35 & 41.28 \\
\hline $\mathrm{T}_{3}$ & 100 & 4.716 & 48.81 & 41.87 \\
\hline $\mathrm{T}_{4}$ & 120 & 4.816 & 49.85 & 41.36 \\
\hline $\mathrm{T}_{5}$ & 140 & 4.624 & 47.86 & 41.27 \\
\hline $\mathrm{T}_{6}$ & 00 & 3.801 & 39.34 & 40.37 \\
\hline $\mathrm{SEm} \pm$ & & $\mathbf{0 . 2 5}$ & $\mathbf{2 . 5 5}$ & $\mathbf{0 . 5 1}$ \\
\hline $\mathrm{CD}$ & & $\mathbf{0 . 7 4}$ & $\mathbf{7 . 7 0}$ & $\mathbf{1 . 5 3}$ \\
\hline
\end{tabular}


Plant growth characters like plant height, ear length, no. of tillers were higher in all treatment compared to control. Among all the treatments $\mathrm{T}_{4}$ was found best with maximum plant height $(94.72 \mathrm{~cm})$, ear length $(9.2 \mathrm{~cm})$ number of tillers/ plant (8.9) in first year and plant height $(94.49 \mathrm{~cm})$ ear length $(9.4 \mathrm{~cm})$ number of tillers per plant (9.1) were found in second year compared to untreated control (Table 3 and 4).

All the treatment having different leveling of nitrogen doses treatments was significantly superior over check. Treatment $\mathrm{T}_{4}$ was found best with $48.28 \mathrm{q} / \mathrm{ha}$ in first year and 49.85 $\mathrm{q} / \mathrm{ha}$ in second year. This treatment was closely followed by $\mathrm{T}_{3}$ and $\mathrm{T}_{5}$. which gave the seed yield $47.25 \mathrm{q} / \mathrm{ha}$ and $48.81 \mathrm{q} / \mathrm{ha}$ in second year, 46.21q/ha $47.86 \mathrm{q} / \mathrm{ha}$ in first and second year, respectively. Similar trend were recorded in case of thousand grain weight. Minimum seed yield $\mathrm{q} / \mathrm{ha}$ and thousand grain weight was recorded with treatment $T_{2}$ compared to untreated control (Table 5 and $6)$.

It can be concluded from the present study the treatment of nitrogen application at $120 \mathrm{~kg}$ $\mathrm{N} / \mathrm{ha}$ made in conjunction with $100 \mathrm{~kg}$ seed rate/ha, are best than all other treatments for achieving the highest traits of expression of number of tillers, ear length $(\mathrm{cm})$, plant height $(\mathrm{cm})$, seed yield (q/ha),1000 grain weight and lower percent disease intensity, AUDPC, thus promising to boost the productivity of wheat (Triticum aestivum L.) in agro-ecological condition of Faizabad region (U.P.). Similar observations were recorded by other workers Yadav et al., (2017) evaluated to study the effect of different seed rate and different doses of nitrogen application on germination percent, purity percent and yield of wheat. The results showed that different doses 100, 120 and 140 $\mathrm{kg} / \mathrm{ha}$ nitrogen and 100, 125 and $150 \mathrm{~kg} / \mathrm{ha}$ seed rate significantly out yielded the 100 $\mathrm{kg} / \mathrm{ha}$ nitrogen and seed rate in seed yield, biological yield. Almost similar result were obtained in case of shoot length, plant height, dry matter (g.), spike length (cm.), number of spike/ear, number of seeds/ spike, 1000 seed weight and harvest index. The application of $140 \mathrm{~kg} \mathrm{~N} / \mathrm{ha}$ and $150 \mathrm{~kg}$ seed rate/ha was the best combination for getting higher seed yield with its better quality. Kandel et al., (2009) elucidated the role of nitrogen in wheat genotypes for management of the disease. Four doses of nitrogen in six different promising genotypes were tested. Nitrogen levels higher than $50 \mathrm{~kg} \mathrm{ha}^{-1}$ significantly reduced disease severity and increased grain yield in all genotypes but there was no significant differences in grain yield in the first year. In the second year, grain yield difference among the genotypes was significant. Area under disease progress curve (AUDPC) was not significant between two doses 100 and $150 \mathrm{~kg} \mathrm{ha}^{-1}$. These results suggested that fertilizer should be applied in soil at balanced dose 100:50:50 N:P2O5:K2O $\mathrm{kg} \mathrm{ha}{ }^{-1}$. Growing relatively resistant genotypes with the balance dose of fertilizers can reduce foliar blight severity in wheat. Singh and Singh (2006) reported the effect of mineral nutrition and environmental variables on the intensity of spot blotch, caused by Cochliobolus sativus (Ito \& Kurib.) Drechs. Ex Dastur, and grain yield in wheat (Triticum aestivum L. emend. Fiori and Paol.). Mean spot blotch intensity being $38.80 \%$ in the first and $38.82 \%$ in the second year, environment mediated difference was not apparent at soft dough stage in the timely sown experiment, but at an intensity of $38.19 \%$ in the second year over $31.20 \%$ in the first, it was very obvious in the late sown one. Environmental variables could not modify the level of spot blotch intensity in timely sown experiment at $120 \mathrm{~kg}$ nitrogen, $60 \mathrm{~kg}$ phosphorus and $40 \mathrm{~kg}$ potash/ha. In the late sown experiment, supplementation of zinc sulphate $(21 \%)$ and elemental sulphur (32.06\%) @ 25 kg/ha each 
to above NPK dose also gave similar results. Maximum intensity enhancement was noted for $180 \mathrm{~kg}$ nitrogen, $60 \mathrm{~kg}$ phosphorus and 40 $\mathrm{kg}$ potash/ha in the first experiment and zero supplementation of potash, zinc sulphate and elemental sulphur to $120 \mathrm{~kg}$ nitrogen and 60 $\mathrm{kg}$ phosphorus in the second.

\section{References}

Anonymous (2016). Project Directorate report (IIW \& BR), Karnal.

Anonymous (2016). United states Department of Agriculture (USDA), Circular Series WAP, 8-16.

Dubin, H.J, Arun, B., Begum, S.N., Bhatta, M., Dhari, R. Goel, L.B. Joshi, A.K., Khanna, B.M., Moloker, P.K., Pokhrel, D.R., Rahman, M.M., Saha, N.K., Shaheed, M.A., Sharma, R.C., Singh, A.K., R.M., Singh, R.V., Vargas, M. and Verma, P.C. (1998). Results of the South Asia Regional Helminthosporium leaf blight and yield experiment, 199394. In: Helminthosporium Blight of wheat: Spot blotch and Tan spot (Eds. Duveiller, E. Dubin, H.J., reeves, J. and Mc Nab, A.). Pp. 182-187.

Kandel., Y. R. and Mahato, J. P (2009). Controlling Foliar Blight of Wheat through Nutrient Management and Varietal Selection Nepal Agric. Res. J., Vol. 9.

Mckinney, H.H. (1975). Foot rot disease of wheat in America. USDA Bull., 1347:40.
Muhammad Yousaf, Muhammad Shaaban, Suliman A, Ibrahim Ali, Shah Fahad, Jamil Khan $\mathrm{M}$ et al., The Effect of Nitrogen Application Rates and Timings of First Irrigation on Wheat Growth and Yield. International Journal of Agriculture Innovations and Research. 2015: 2(4):645-653.

Parveen Kousar, Liaquat Ali, Amber Raza, Ammarah Maqbool, Saman Maqbool, Sana Rasheed et al., Effect of different levels of nitrogen on the economic yield of Wheat (Triticum aestivum L.) variety Aas-11. International Journal of Agronomy and Agricultural Research (IJAAR). 2015; 6(3):7-11.

Satyanarayana M. Response of different Wheat (Triticum aestivum L.) varieties to graded levels of nitrogen - a critical review. International Journal of Applied Biology and Pharmaceutical Technology. 2015; 6(3):241-248.

Singh V and Singh R.N. (2006). Effect of mineral nutrition and environmental variables on the intensity of wheat spot blotch under rice-wheat system. Indian Phytopathology., 59 (4): 417-426.

Yadav, M.S. and Dhanai, C.S. (2017). Effect of different doses of nitrogen and seed rate on various characters and seed yield of wheat (Triticum aestivum L.) J. Pharmacognosy and Phytochemistry., 6(2): 01-05.

\section{How to cite this article:}

Ghanshyam Verma, S.P. Singh, S.K. Singh, Chandra Pal, Sheetala Varma and Nutan Singh. 2018. Effect of Different Nitrogen Doses on Various Characters against Foliar Blight of Wheat (Triticum aestivum L.). Int.J.Curr.Microbiol.App.Sci. 7(11): 1918-1924. doi: https://doi.org/10.20546/ijcmas.2018.711.217 